\title{
Cadmium Accumulation by a Citrobacter sp.
}

\author{
By LYNNE E. MACASKIE AND A. C. R. DEAN* \\ Physical Chemistry Laboratory, University of Oxford, South Parks Road, \\ Oxford OXI $3 Q Z, U K$
}

(Received 8 July 1983; revised 19 September 1983)

\begin{abstract}
Cadmium accumulation by a Citrobacter sp. growing in the presence of the metal occurred as a sharp peak during the mid-exponential phase of growth, but cultures showed considerable inhibition of growth compared to cadmium-free controls. This problem was overcome by pregrowing the cells in cadmium-free medium and subsequently exposing them to the metal in the resting state, under which conditions higher concentrations of cadmium were tolerated and metal uptake was enhanced. This ability was retained when the cells were immobilized and then challenged with a flow containing $\mathrm{Cd}^{2+} ; 65 \%$ of the metal presented was removed from solution. The influence on uptake of the composition of the exposure buffer and of various cell treatments were investigated and the results are discussed with respect to the anticipated speciation of the cadmium presented to the cells and also with respect to the probable mechanism of metal uptake. This is thought to occur through the activity of a cell-bound phosphatase, induced during pre-growth by the provision of glycerol 2-phosphate as sole phosphorus source. Continued enzyme function in resting cells would then precipitate the metal as cell-bound cadmium phosphate.
\end{abstract}

\section{INTRODUCTION}

Cadmium, commonly present in wastes from various mining, smelting and electroplating industries, has no known biological function and is highly toxic to man and other forms of life (Vallee \& Ulmer, 1972; Chang et al., 1981). World Health Organization recommendations as to acceptable daily intake by humans are currently under review (see Piscator, 1981) and interest in the effects of human exposure via food chains in cadmium-polluted areas (e.g. Strehlow \& Barltrop, 1981) and the known lethality of the metal in cases of extreme exposure (Kobayashi, 1970) have focused attention on the desirability of its removal from sources of pollution.

We have investigated the feasibility of using micro-organisms to concentrate cadmium from solution, with a view to the removal of soluble forms of the metal from industrial liquid wastes. Several reports exist of cadmium accumulation by micro-organisms (e.g. Chopra, 1971; McLean et al., 1972; Norris \& Kelly 1977; Hassett et al., 1980) and uptakes as high as 8\% (Bacillus cereus) and $15 \%$ (Aspergillus niger) of the organisms' dry weight have been reported (Doyle et al., 1975). However, these uptakes were obtained using rich culture media, components of which form complexes with heavy metals (Ramamoorthy \& Kushner, 1975), but to an extent which is difficult to define (Stumm \& Bilinski, 1972). If the chelating ligand is a substrate molecule utilized by the cells, metal accumulation may be enhanced (Sterritt \& Lester, 1980a). Alternatively, chelation to a non- or lesser-utilized component of the medium may reduce the toxicity of metal ions (Pickett \& Dean, 1976, 1979; Sterritt \& Lester, 1980b; Babich \& Stotzky, 1980 ) but metal uptake may also be reduced (Baldry \& Dean, $1980 a, b$ ). In order to determine cadmium uptake in the absence of excessively-chelating ligands, and because industrial effluents are likely to be nutritionally sparse, our studies were performed in minimal media.

The Citrobacter sp. used in this work was isolated from metal-polluted soil and fulfilled the necessary criteria of a high uptake of cadmium (up to $1.6 \%$ of the organism's dry weight), 
coupled with a high resistance to the metal when grown in its presence (Macaskie \& Dean, 1982). This is of importance, since metal resistance is often by exclusion of the metal from the cells, with correspondingly low uptake (Chopra, 1971; Tynecka et al., 1975; Kondo et al., 1974; Foster, 1977; Baldry \& Dean, 1980 ; Macaskie \& Dean, 1982). However, even this cadmiumresistant strain tolerated only $100 \mu \mathrm{g} \mathrm{Cd}^{2+} \mathrm{ml}^{-1}$ in minimal growth medium (Macaskie \& Dean, 1982). The uptake of cadmium by micro-organisms is reported to be related to the concentration of the metal in the medium (Doyle et al., 1975; Tynecka et al., 1975), but it was not feasible to increase further the $\mathrm{Cd}^{2+}$ concentration in minimal medium due to its toxicity to growing cells. However, if the cells were pre-grown in cadmium-free medium and then exposed to the metal in the non-growing (resting) state, higher concentrations could be used and the uptake was enhanced (Macaskie \& Dean, 1982). Clearly this approach is preferable, since an industrial process might envisage the use of pre-grown, immobilized organisms as a filter through which metal-containing effluent could be passed. A detailed investigation of the uptake of cadmium by growing and resting cells of the Citrobacter $\mathrm{sp}$. is reported here, and the activity of immobilized resting cells in a flow of cadmium-containing medium is determined.

\section{METHODS}

Organism. The organism was isolated from lead-polluted soil as described previously (Aickin \& Dean, 1977) and was identified as a species of Citrobacter by the staff maintaining the National Collection of Industrial Bacteria (Torry Research Station, Aberdeen, Scotland).

Media. Minimal media contained (g 1 $\left.{ }^{-1}\right): \mathrm{FeSO}_{4} .7 \mathrm{H}_{2} \mathrm{O}, 0.32 \times 10^{-3} ; \mathrm{MgSO}_{4} .7 \mathrm{H}_{2} \mathrm{O}, 0.063 ; \mathrm{KCl}, 0.62$; glycerol 2-phosphate (disodium salt hydrate, $\left.5 \cdot 5 \mathrm{H}_{2} \mathrm{O}\right), 0.67 ;\left(\mathrm{NH}_{4}\right)_{2} \mathrm{SO}_{4}, 0.96$; Tris, 12.0; glucose or glycerol, 1.5 . Where appropriate, cadmium was incorporated as $3 \mathrm{CdSO}_{4} .8 \mathrm{H}_{2} \mathrm{O}$ to the required final concentration of $\mathrm{Cd}^{2+}$ The $\mathrm{pH}$ was adjusted to 7.0 with $2 \mathrm{M}-\mathrm{HCl}$. All chemicals used were of 'Analar' grade, except for the glycerol 2phosphate and the MOPS (see later), which were reagent grade (BDH).

Growth of organisms. The Citrobacter sp., pre-adapted to the minimal medium by several serial subcultures, was grown in minimal medium $\left(20^{\circ} \mathrm{C}\right)$ with aeration and agitation provided by vigorous streams of sterile air. Growth was followed turbidimetrically using a Hilger Spekker photoelectric absorptiometer and the turbidity readings were related to bacterial dry weight (biomass) $\mathrm{ml}^{-1}$ using a calibration plot. Bacterial dry weights were determined by harvesting the organisms by centrifugation, washing the bacterial pellet once with water and then drying it to constant weight at $105^{\circ} \mathrm{C}$. Starter cultures were pre-grown in cadmium-free medium to $120 \mu \mathrm{g}$ biomass $\mathrm{ml}^{-1}$ and inoculated into the main flask to a final volume of $850 \mathrm{ml}$. The initial cell concentrations were $1.2 \mu \mathrm{g}$ biomass $\mathrm{ml}^{-1}$ (for experiments using cadmium-containing media) or $24 \mu \mathrm{g}$ biomass $\mathrm{ml}^{-1}$ (cadmium-free batch cultures for subsequent determination of $\mathrm{Cd}$ uptake by resting cells).

Cadmium uptake by organisms growing in cadmium-containing media. Cultures were generally harvested at a biomass of $50 \mu \mathrm{g}$ dry wt organisms $\mathrm{ml}^{-1}$, since preliminary experiments showed that the cadmium uptake reached its maximum when this biomass had been attained. Samples (biomass approximately $4 \mathrm{mg}$ ) were harvested, washed in distilled water and dried to constant weight at $105^{\circ} \mathrm{C}$. The pellets were then heated with a mixture of concentrated nitric and sulphuric acids $\left(280^{\circ} \mathrm{C}\right)$ until a clear solution was obtained. The acid digests were neutralized with $2 \mathrm{M}-\mathrm{KOH}$ against phenolphthalein, diluted to $100 \mathrm{ml}$ with distilled water and assayed for their cadmium contents by anodic stripping voltammetry (Aickin \& Dean, 1977).

Cadmium uptake by resting organisms. Samples (biomass $9.6 \mathrm{mg}$ per sample) were removed from batch cultures, harvested by centrifugation and washed once in isotonic saline $\left(8.5 \mathrm{~g} \mathrm{NaCl}^{-1}\right)$. Where whole-culture harvests were required, the culture was harvested at a biomass of $0.12 \mathrm{mg} \mathrm{dry} \mathrm{wt} \mathrm{ml} \mathrm{m}^{-1}$, corresponding to $8 \mathrm{~h}$ of growth. The pellets were resuspended at $0.12 \mathrm{mg}$ biomass $\mathrm{ml}^{-1}$ in either Tris (100 mM) or MOPS (100 mM) buffer, supplemented with glycerol 2-phosphate ( $2 \mathrm{mM}$ ) and cadmium sulphate. The pH was adjusted to 7.0 using either $2 \mathrm{M}-\mathrm{HCl}$ (Tris buffer) or $2 \mathrm{M}-\mathrm{NaOH}$ (MOPS buffer) prior to adjusting the final resuspension volume to $80 \mathrm{ml}$. The cell suspensions were incubated $\left(20^{\circ} \mathrm{C}\right)$ with agitation for $18 \mathrm{~h}$ and the organisms were harvested and assayed for their cadmium contents as described above. Where appropriate, sonication was performed using an MSEMullard ultrasonic disintegrator $(5 \mathrm{~min})$ prior to cadmium addition to the resuspensions. Toluene treatment was performed by the incorporation of eight drops of toluene to each $80 \mathrm{ml}$ resuspension throughout the duration of cadmium exposure, where required.

Immobilization of the Citrobacter sp. in a polyacrylamide gel, and cadmium uptake by immobilized organisms. A culture of the Citrobacter sp. (2.5 l; glycerol medium) was grown to stationary phase, harvested and washed twice in isotonic saline $(300 \mathrm{ml})$. The pellet was drained by inversion, and $5 \mathrm{~g}$ wet wt cell pellet was resuspended in $40 \mathrm{ml}$ saline supplemented with $5 \mathrm{~g}$ acrylamide monomer, $0.5 \mathrm{~g} N, N$-methylenebisacrylamide and one drop of PPG antifoam. Nitrogen gas (oxygen-free) was passed through the suspension for $2 \mathrm{~min} ; 5 \mathrm{ml}$ of a $2.5 \%$ (w/v) aqueous solution of potassium persulphate and $5 \mathrm{ml}$ of a $5 \%(\mathrm{w} / \mathrm{v})$ aqueous solution of 3-dimethylaminopropiononitrile 

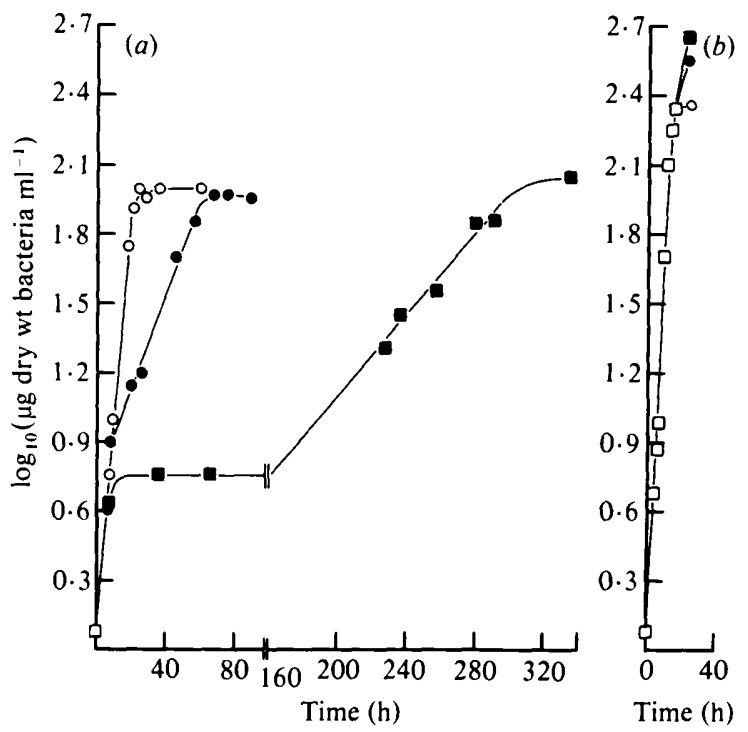

Fig. 1. Effect of the initial pH of the medium on the growth of the Citrobacter sp. $(a)$ in the presence of $\mathrm{Cd}^{2+}\left(20 \mu \mathrm{g} \mathrm{ml}^{-1}\right)$ and $(b)$ in the absence of the metal. $\mathrm{O}, \mathrm{pH} 6.5 ; \mathrm{pH} 7 \cdot 0 ; \mathrm{q}, \mathrm{pH} 7 \cdot 5 ; \square$, all three $\mathrm{pH}$ values.

were then added to initiate polymerization. The suspension was shaken gently until the gel began to set and was then refrigerated $\left(4^{\circ} \mathrm{C}\right)$ throughout polymerization to prevent thermal damage to the cells. The gels were prepared in glass cylinders stoppered at each end. When the gel had set, these stoppers were removed and the gel was shredded by forcing it through a stainless steel sieve $(20$ mesh per $2.5 \mathrm{~cm})$. The shredded gels were packed in glass columns $(10 \mathrm{~cm} \times 3 \mathrm{~cm})$, washed with 21 isotonic saline and allowed to drain at room temperature. The column and tubing were pre-equilibrated with $\mathrm{Tris} / \mathrm{H}_{2} \mathrm{SO}_{4}$ buffer $(100 \mathrm{mM}, \mathrm{pH} 7 \cdot 0)$ containing glycerol 2-phosphate ( $2 \mathrm{mM})$ and were similarly drained. A solution of this buffer supplemented with cadmium sulphate $\left(200 \mu \mathrm{g} \mathrm{Cd}^{2+} \mathrm{ml}^{-1}\right)$ was then pumped upwards $\left(60 \mathrm{ml} \mathrm{h}^{-1}\right)$ through the column at room temperature and the column outflow was assayed for residual $\mathrm{Cd}^{2+}$ by anodic stripping voltammetry (Aickin \& Dean, 1977).

\section{RESULTS AND DISCUSSION}

\section{Effect of culture $\mathrm{pH}$ on the uptake and toxicity of cadmium}

The toxicity of cadmium towards some bacteria increases with increasing culture pH (Babich \& Stotzky, 1977; Korkeala \& Pekkanen, 1978). The effect of the initial pH of the growth medium on the uptake of cadmium by the Citrobacter sp. and on its toxicity were therefore examined. The highest $\mathrm{pH}$ tested was $7 \cdot 5$, since at this and lower $\mathrm{pH}$ all of the free cadmium in the medium is in the form of $\mathrm{Cd}^{2+}$, and the $\mathrm{CdOH}^{+}$species, which starts to appear at $\mathrm{pH}$ values above 7.5 (Hahne \& Kroontje, 1973), may differ in its toxicity to bacteria as compared to $\mathrm{Cd}^{2+}$ (Babich \& Stotzky, 1977, 1980). The toxicity of cadmium towards the Citrobacter sp. was found to be $\mathrm{pH}$ dependent (Fig. 1). In the presence of the metal $\left(20 \mu \mathrm{g} \mathrm{ml}^{-1}\right)$, the doubling time was

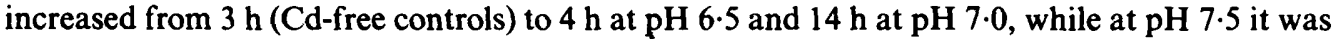
$34 \mathrm{~h}$ and the exponential phase was preceded by a lag of about $160 \mathrm{~h}$. At pH values above 6.5 a biphasic growth pattern was observed; an initially rapid phase of growth preceded a longer and slower phase during which the doubling time was determined. The final cell concentrations in the Cd cultures were reduced compared to the controls. It was found that the uptake of cadmium was reduced to $0.52 \pm 0.12 \%$ (mean \pm SEM, eight experiments) of the bacterial dry weight at $\mathrm{pH} 6.5$, compared to the results obtained at $\mathrm{pH} 7.0$ and 7.5 , which were very similar at $1.89 \pm$ $0.09 \%$ and $1.97 \pm 0.32 \%$ (means \pm SEM, eight experiments) of the bacterial dry weight, respectively. To ensure maximum cadmium uptake consistent with only moderate toxicity, an initial $\mathrm{pH}$ of 7.0 was chosen for a more detailed investigation of the accumulation of the metal during the growth cycle. 


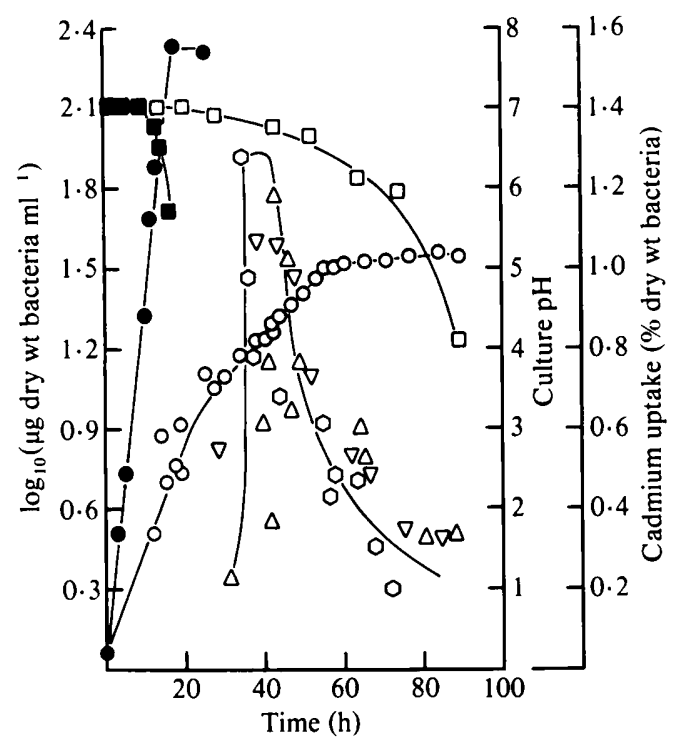

Fig. 2

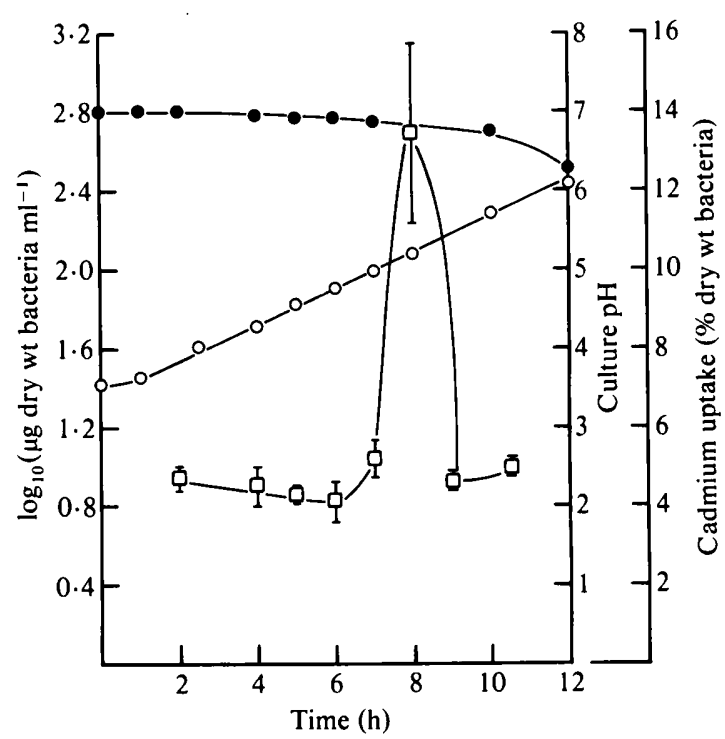

Fig. 3

Fig. 2. Cadmium accumulation by the Citrobacter sp. growing in minimal medium (initial pH 7.0) containing $\mathrm{Cd}^{2}+\left(50 \mu \mathrm{g} \mathrm{ml}^{-1}\right)$. Open symbols, cadmium-treated culture; closed symbols, cadmium-free control. $\bigcirc, \bigcirc$, bacterial growth (expressed as dry wt); $\square, \square, \mathrm{pH}$ of culture; $\Delta, \nabla, 0$, cadmium uptake $(\%$ bacterial dry wt). Data are from three independent experiments.

Fig. 3. Cadmium accumulation by resting cells of the Citrobacter sp. The organisms were pre-grown in cadmium-free glucose medium and the uptake of cadmium by washed resting cells was determined by incubating them for $18 \mathrm{~h}$ at $20^{\circ} \mathrm{C}$ in Tris buffer $(100 \mathrm{mM}, \mathrm{pH} 7.0)$ containing $\mathrm{Cd}^{2+}\left(1 \mathrm{mg} \mathrm{ml}^{-1}\right)$ and glycerol 2-phosphate $(2 \mathrm{~mm})$. $\bigcirc$, Bacterial growth (dry wt); $\bigcirc$, culture $\mathrm{pH} ; \square$, cadmium uptake. The changes in bacterial dry weight and in culture $\mathrm{pH}$ refer to the pre-growth in cadmium-free medium and are given to show the stages of the growth cycle at which samples were withdrawn for resting uptake determinations. No growth occurred in these uptake experiments and the uptake data shown are mean values ( \pm SEM) obtained from three experiments, except for the value obtained after $8 \mathrm{~h}$ of pre-growth which refers to 15 experiments.

\section{Cadmium accumulation during the growth cycle}

The uptake of cadmium by growing cells was observed to rise sharply during the midexponential phase to a maximum at a cell concentration of about $50 \mu \mathrm{g}$ dry wt organisms $\mathrm{ml}^{-1}$ and then declined, corresponding to a fall in the $\mathrm{pH}$ of the growth medium (Fig. 2). This cadmium uptake profile is similar to that found with copper and Escherichia coli (Baldry \& Dean, $1980 \mathrm{a}$ ), except that in the present study maximum accumulation of the metal occurred during the mid- and not the late-exponential phase. Copper was accumulated at acid pH by $E$. coli (Baldry \& Dean, 1980a), whereas in the present work the amount of cadmium taken up at $\mathrm{pH}$ below 6.5 was low. The fall in the cadmium uptake corresponded to a diluting out of the metal in the growing cells. However, no decrease in the toxicity of the metal (as evidenced by more rapid growth in the later exponential phase) was observed as the $\mathrm{pH}$ of the medium fell, suggesting that following its initial adsorption the metal remained bound to the cells, as was the case with $E$. coli (Baldry \& Dean, 1980a) and Staphylococcus aureus (Tynecka et al., 1975).

A known toxic effect of cadmium is uncoupling of oxidative phosphorylation (Vallee \& Ulmer, 1972), and increased oxygen uptake by cadmium-treated bacteria has been observed (Huang \& Kao, 1981). A shift of bacterial metabolism towards less efficient, fermentative growth may lead to an increase in organic acid formation and a fall in $\mathrm{pH}$ in cadmium-treated cultures. The possibility that an extrusion mechanism is operative only at acid $\mathrm{pH}$ is not precluded, but this is unlikely since no recovery was observed as the $\mathrm{pH}$ and cadmium uptake fell.

The fine balance between maximum uptake and minimum toxicity towards the cells may be difficult to achieve in an industrial situation. Also, the cell concentration at which maximum 
uptake occurs may vary. These problems may be overcome if the cells are pre-grown in cadmium-free medium and then exposed to the metal in the non-growing (resting) state. The remainder of this communication deals exclusively with resting cells and it should be emphasized that no growth occurred in these experiments. The buffered solutions in which the organisms were exposed to cadmium were nutritionally incomplete and the high concentration of the metal used would be growth-inhibitory.

\section{Uptake of cadmium by resting cells of the Citrobacter sp.}

Using glucose as the pre-growth carbon source (doubling time $3 \mathrm{~h}$ ), it was found that the inherent ability of the cells to accumulate cadmium maximally upon subsequent exposure to the metal in the resting state was present as a sharp and distinct peak in cells withdrawn after $8 \mathrm{~h}$ growth in the cadmium-free medium (Fig. 3). Prior to and subsequent to this point, the uptake of cadmium by resting cells was only $4-5 \%$ of the organisms' dry weight. This uptake profile is very similar in shape (although on a different time scale) to that observed with growing cells (Fig. 2), but in this case the potential of the cells to accumulate cadmium had started to decline before the $\mathrm{pH}$ of medium had begun to fall appreciably. Using resting cells and a cadmium concentration of $1000 \mu \mathrm{g} \mathrm{ml}^{-1}$, it was found that samples withdrawn after $8 \mathrm{~h}$ pre-growth had subsequent cadmium uptakes of $13.5 \pm 2.2 \%$ (mean \pm SEM, 15 experiments; range $5.0-26.8 \%$ ) of the organisms' dry weight. This wide range of uptakes may have been due to slight inconsistencies in the exact time of the appearance of the peak of potential to accumulate cadmium in the resting state. Nevertheless, each of the 15 batches of cells was consistent within itself with respect to the response of the cells to the effect of various treatments on cadmium uptake. Thus in some subsequent experiments, each $850 \mathrm{ml}$ batch was divided into 'control' and 'treated' portions after harvesting. The uptake of cadmium by the internal control portion was expressed as $100 \%$, irrespective of where the absolute uptake fell in the 5.0-26.8\% range. The uptake of cadmium by the treated portion was expressed as a percentage of this control value. Using this approach, it was established that the treatment of the cells prior to cadmium exposure affected their potential to accumulate the metal. Storage of the cells for $7 \mathrm{~d}$ at $4{ }^{\circ} \mathrm{C}$ after harvest increased their cadmium uptake by $57 \cdot 1 \pm 8 \cdot 6 \%$ (mean \pm SEM, three experiments) as compared to freshly harvested cells. However, disruption of the latter with toluene during cadmium exposure did not affect the uptake of cadmium, while ultrasonication prior to cadmium exposure was found to reduce uptake of the metal to $68 \cdot 6 \pm 8 \cdot 7 \%$ (mean \pm SEM, four experiments) of the value obtained using freshly harvested intact cells.

Stringent controls were employed throughout to ensure that no cadmium precipitation occurred in the absence of bacteria.

\section{Factors affecting the uptake of cadmium by resting cells}

Uptake of cadmium by resting cells was linear with respect to time in the presence of glycerol 2-phosphate in the resuspension buffer (Fig. 4). In the absence of glycerol 2-phosphate, cadmium uptake was only $3.4 \pm 0.6 \%$ (mean \pm SEM, three experiments) of the organisms' dry weight after $18 \mathrm{~h}$ of incubation, and remained essentially unchanged even upon extended incubation (Fig. 4). In accordance with earlier work (Doyle et al., 1975), cadmium uptake was found to increase with the concentration of the metal (Table 1). However, the given concentration is not the concentration of the free $\mathrm{Cd}^{2+}$ species, since cadmium binds to some extent with Tris $\left(\log K_{\mathrm{f}}=5.46\right.$ at a Cd/Tris ratio of $2.20 ;$ Brignac \& $\left.\mathrm{Mo}, 1975\right)$, and given that glycerol 2-phosphate is also present and may also complex the metal, the concentration of the free $\mathrm{Cd}^{2+}$ is difficult to ascertain (Pickett \& Dean, 1976). The former is illustrated by the data of Fig. 5. MOPS buffer complexes metals negligibly (Good et al., 1966), and the concentration of free $\mathrm{Cd}^{2+}$ would be significantly increased. It was found (Fig. 5) that, whereas in $\mathrm{Tris} / \mathrm{HCl}$ buffer containing 50 and $100 \mu \mathrm{g} \mathrm{Cd}^{2+} \mathrm{ml}^{-1}$, uptake was very low, this was increased to $28 \%$ at only $50 \mu \mathrm{g} \mathrm{Cd}^{2+} \mathrm{ml}^{-1}$ in MOPS/NaOH buffer. Moreover, the uptake of cadmium by resting cells (Table 1), in contrast to the situation with growing cells, was increased at $\mathrm{pH} 7 \cdot 5$, although uptake was reduced at acid $\mathrm{pH}$ in both cases. It could be argued that the $\mathrm{HCl}$ required to adjust the $\mathrm{pH}$ to 6.5 may have complexed the $\mathrm{Cd}^{2+}$ as $\mathrm{CdCl}^{+}$(Hahne \& $\mathrm{Kroontje}, 1973$ ) and reduced its 


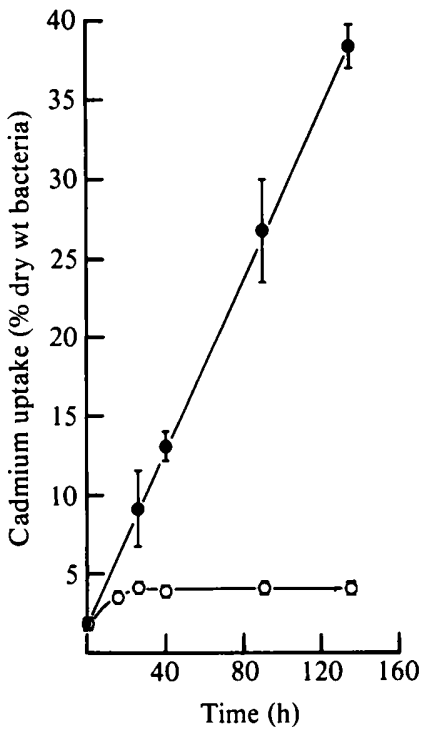

Fig. 4

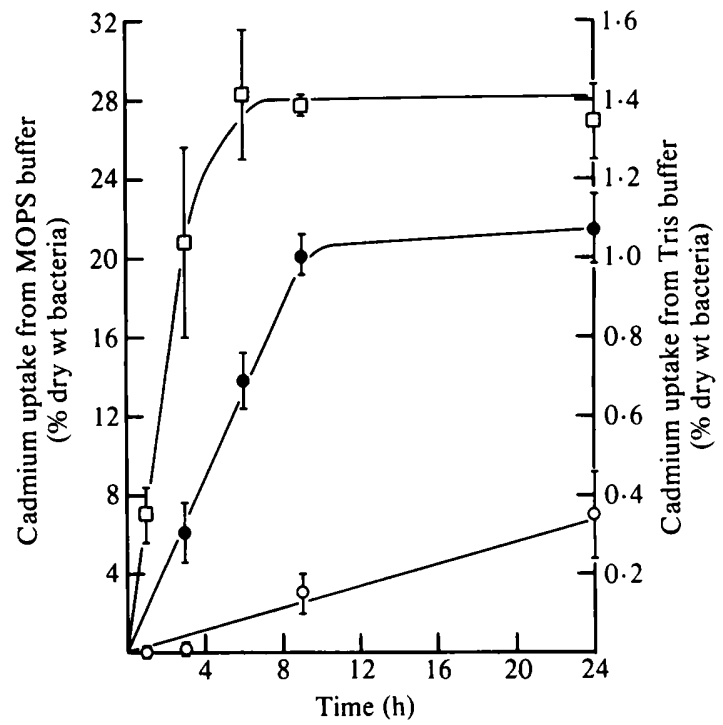

Fig. 5

Fig. 4. Time course of cadmium accumulation by resting cells of the Citrobacter sp. The organisms were pre-grown in cadmium-free glucose medium, harvested at a biomass of $0.12 \mathrm{mg}$ dry wt ml $\mathrm{ml}^{-1}$ (corresponding to $8 \mathrm{~h}$ pre-growth) and the uptake of cadmium by washed resting cells was then determined using Tris buffer containing $\mathrm{Cd}^{2}+\left(1 \mathrm{mg} \mathrm{ml}^{-1}\right)$ and, when necessary, glycerol 2-phosphate ( $2 \mathrm{mM}$ ). The suspensions were incubated at $20^{\circ} \mathrm{C}$ and samples were withdrawn at the times shown. $\bigcirc$, Cadmium uptake in the absence of glycerol 2-phosphate; $O$, cadmium uptake in the presence of glycerol 2-phosphate. Data shown are mean values $( \pm$ SEM) from three experiments.

Fig. 5. Effect of resuspension buffer on the uptake of cadmium by resting cells of the Citrobacter sp. Organisms pre-grown and harvested as described in Fig. 4 were resuspended in Tris buffer or MOPS buffer containing glycerol 2-phosphate $(2 \mathrm{mM})$ and $\mathrm{Cd}^{2+}$ as described below. The uptake of cadmium was determined in samples withdrawn at the times shown. $\bigcirc$, Cadmium uptake from Tris buffer containing $\mathrm{Cd}^{2}+\left(50 \mu \mathrm{g} \mathrm{ml}^{-1}\right) ; 0$, cadmium uptake from Tris buffer containing $\mathrm{Cd}^{2+}\left(100 \mu \mathrm{g} \mathrm{ml}^{-1}\right)$; $\square$, cadmium uptake from MOPS buffer containing $\mathrm{Cd}^{2+}\left(50 \mu \mathrm{g} \mathrm{ml}^{-1}\right)$. Data are the mean values $( \pm \mathrm{SEM})$ from three experiments.

affinity for the bacterial cells. However, the amount of $\mathrm{HCl}$ required to effect this $\mathrm{pH}$ change in Tris buffer is very small, and the progression of the speciation of cadmium through $\mathrm{Cd}^{2+}$, $\mathrm{CdCl}^{+}$and $\mathrm{CdCl}_{2}$ occurs at exponentially increasing concentrations of chloride (Hahne \&

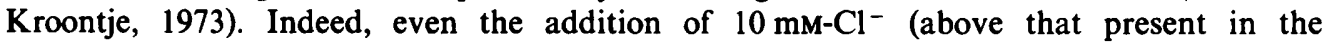
'background' buffer) did not affect cadmium uptake (Table 1). However, cadmium uptake was reduced by the addition of $100 \mathrm{mM}^{-\mathrm{Cl}^{-}}$(Table 1), consistent with a shift in metal speciation towards the complexed form. These results are in agreement with those of Wong et al. (1979), using a unicellular green alga, and with the observed inhibitory effect of chloride on the uptake of copper by $E$. coli (Baldry \& Dean, 1980b). Similarly, it was observed that fluoride was inhibitory to cadmium uptake (Table 1 ). However, this was probably not solely due to metalhalide complex formation, since inhibition was observed at $10 \mathrm{~mm}-\mathrm{F}^{-}$(c.f. $10 \mathrm{~mm}-\mathrm{Cl}^{-}$). At $100 \mathrm{~mm}$-halide (additional to that present in the buffer 'background') inhibition was similar with $\mathrm{Cl}^{-}$and $\mathrm{F}^{-}$. Mercaptoethanol (10 mM) was also found to reduce cadmium uptake (Table 1), probably due to interaction of $\mathrm{Cd}^{2+}$ with the $-\mathrm{SH}$ group (Babich \& Stotzky, 1980) with similar removal of the metal from a freely-available form.

These results emphasize the need to relate cadmium uptake to the speciation of the metal in the growth medium or resuspension buffer. This problem of interpretation of results is described by Stumm \& Bilinski (1972), and stresses the ideal requirement for a cadmium solution containing no other components. However, this may not be feasible in a biological system, and in the buffered system employed here, the $\mathrm{Cd}^{2+}$ would, to some degree, form complexes with Tris, $\mathrm{Cl}^{-}$and glycerol 2-phosphate, possibly with more than one ligand simultaneously. 
Table 1. Effect of various factors on the uptake of cadmium by resting cells of the Citrobacter sp.

The organisms were pre-grown in cadmium-free glucose medium and harvested after $8 \mathrm{~h}$ growth. In the control, the uptake of cadmium by washed resting cells was determined by incubating them for $18 \mathrm{~h}$ at $20^{\circ} \mathrm{C}$ in Tris buffer $(100 \mathrm{mM}, \mathrm{pH} 7.0)$ containing $\mathrm{Cd}^{2+}\left(1000 \mu \mathrm{g} \mathrm{ml}^{-1}\right)$ and glycerol 2-phosphate $(2 \mathrm{~mm})$. Variations were introduced as shown below and the cadmium uptakes obtained in these conditions were expressed as percentages of that obtained in the control. The results are expressed as mean values \pm SEM; the number of experiments is given in parentheses.

Treatment

Cadmium ( $\mu \mathrm{g} \mathrm{ml}^{-1}$ )

400

200

100
50

25

$\mathrm{pH}$

$6 \cdot 5$

$7 \cdot 5$

Halide ions (mM)

$\mathrm{NaCl}, 10$

$\mathrm{NaCl}, 100$

$\mathrm{NaF}, 10$

$\mathrm{NaF}, 100$

Mercaptoethanol (mM)

10
Cadmium accumulated

( $\%$ of control)

$$
\begin{array}{r}
46.8 \pm 6.2(4) \\
25.8 \pm 1.4(4) \\
13.0 \pm 0.5(4) \\
7.3 \pm 1.0(4) \\
5.5 \pm 0.9(4) \\
66.4 \pm 2.1(4) \\
130.6 \pm 3.9(4) \\
96.3 \pm 7.1(3) \\
49.5 \pm 5.4(3) \\
60.3 \pm 4.6(3) \\
53.4 \pm 7.0(3) \\
18.4 \pm 3.0(3)
\end{array}
$$

\section{Uptake of cadmium by cells pre-grown in glycerol}

If the cells were pre-grown in glycerol medium before subsequent exposure to cadmium in the resting state, they retained the potential to accumulate the metal maximally throughout the growth cycle and not as a sharp peak as was the case with cells pre-grown in glucose. For example, the cadmium uptake of cells harvested after $4 \mathrm{~h}$ growth in glycerol medium was 12.22 $\pm 1.07 \%$ (mean \pm SEM, six experiments) of the organisms' dry weight and the corresponding uptakes obtained at $8 \mathrm{~h}$ and $12 \mathrm{~h}$ were $11.78 \pm 1.08 \%(15$ experiments) and $10.79 \pm 1.41 \%$ (four experiments), respectively. These uptakes are very similar to the maximum uptake obtained in identical conditions with cells pre-grown in glucose medium (Fig. 3). Since a large biomass of cells was required for immobilized cell preparations, glycerol-pregrown cells were subsequently employed because they could be harvested during the stationary phase of growth with no loss in cadmium-accumulating activity.

\section{Cadmium uptake by immobilized cells of the Citrobacter sp.}

When the Citrobacter sp. was immobilized in a polyacrylamide gel and challenged with buffer containing $\mathrm{Cd}^{2}+\left(200 \mu \mathrm{g} \mathrm{ml}^{-1}\right)$, in the presence of glycerol 2-phosphate, the immobilized cells reproducibly removed a high level of cadmium from solution (Table 2). Indeed, when $150 \mathrm{ml}$ buffer had passed through the column of immobilized cells, $130 \mu \mathrm{g} \mathrm{cadmium} \mathrm{ml}^{-1}$, representing $65 \%$ of that available, had been removed. In contrast, cell-free preparations removed little $\mathrm{Cd}^{2+}$ and Table 2 also shows that the efficiency of the immobilized cell preparations remained unabated until 1 litre of the buffer had passed through the column and then began to decline slowly. A similarity between these results and those obtained previously (Aickin \& Dean, 1979) for the removal of lead by immobilized cells of another Citrobacter sp. is evident and in molar terms the concentration of lead employed by Aickin \& Dean (1979) and the cadmium concentration employed here were quite similar at $2.4 \mathrm{mM}$ and $1.8 \mathrm{mM} \mathrm{Pb}^{2+}$ and $\mathrm{Cd}^{2+}$, respectively. The lead-removing and the cadmium-removing Citrobacter spp. were not different isolates of the same strain. Work carried out in this laboratory showed that immobilized cells of 
Table 2. Cadmium accumulation by immobilized cells of the Citrobacter sp.

The Citrobacter sp. was pre-grown, immobilized and columns of immobilized organisms were prepared as described in Methods. Cadmium-buffer $\left(200 \mu \mathrm{g} \mathrm{Cd}^{2+} \mathrm{ml}^{-1}\right)$ was then pumped through the columns. I, II and III were three independent gel preparations. ND, Not determined.

\begin{tabular}{|c|c|c|c|c|c|c|}
\hline \multirow{3}{*}{$\begin{array}{c}\text { Elution } \\
\text { volume } \\
(\mathrm{ml})\end{array}$} & \multicolumn{6}{|c|}{$\mathrm{Cd}^{2+}$ in solution leaving column $\left(\mu \mathrm{g} \mathrm{ml}^{-1}\right)$} \\
\hline & \multicolumn{3}{|c|}{ Immobilized cell column } & \multicolumn{3}{|c|}{ Cell-free column } \\
\hline & I & II & III & I & II & III \\
\hline 150 & 67 & 70 & 73 & 148 & 149 & 154 \\
\hline 500 & 68 & 69 & ND & 192 & 198 & ND \\
\hline 1000 & 68 & 69 & ND & 200 & 194 & ND \\
\hline 3000 & 76 & 80 & ND & 200 & 203 & ND \\
\hline 5000 & 86 & 80 & ND & 204 & 198 & ND \\
\hline
\end{tabular}

the lead-removing Citrobacter sp. were ineffective in the removal of $\mathrm{Cd}^{2+}$ from solution (R. M. Aickin, unpublished observations) and the two strains differed in their responses to some classification tests (N.C.I.B. report, Torry Research Station).

The similarity between lead removal by the Citrobacter sp. of Aickin \& Dean (1979) and the cadmium removal reported here, and the close taxonomic relationship of the two organisms, point to a similar underlying mechanism of metal uptake. With lead, this has been shown to occur through the use of a cell-bound phosphatase induced during pre-growth by the provision of glycerol 2-phosphate as sole phosphorus source, which liberates inorganic phosphate in excess of that required for growth. The enzyme continues to function in resting cells and the phosphate released precipitates with lead as cell-bound lead phosphate, $\mathrm{PbHPO}_{4}$ (Aickin \& Dean, 1979; Aickin et al., 1979). Since cadmium and lead phosphates are similarly insoluble, it seems likely that cadmium would also be precipitated. Although the mechanism of cadmium accumulation awaits further study, several lines of evidence point to an enzymic process. The observed linearity of the reaction with time, and the requirement for glycerol 2-phosphate as a cofactor are indicative of this, and the mechanism is concluded to be surface-bound, since cell disruption did not increase cadmium uptake. It has been reported that the carbon source content of the medium influences the phosphatase activity of Klebsiella aerogenes (Bolton \& Dean, 1972) and Bacillus subtilis (Ghosh \& Ghosh, 1972), which may explain why the cadmium-uptake ability of the Citrobacter sp. was maintained throughout growth in glycerol medium but was present as a sharp peak in glucose medium. The influence of the carbon source on the phosphatase activity of this organism is currently under investigation.

The toxicity of cadmium to growing cells, in contrast to the lead tolerance observed in the lead-accumulating Citrobacter sp. (Aickin \& Dean, 1979) may be explained in terms of the known toxicity of the metal towards phosphatases (Pickett et al., 1976). This may occur by substitution of cadmium for zinc atoms, (required for formation of active enzyme), with impairment of activity (Lazdunski et al., 1969; Applebury et al., 1970). If phosphatase acts to 'protect' the cells from heavy metal toxicity by precipitation of the metals with phosphate exocellularly, then a functionally impaired enzyme may permit access of the metal to the cells and inhibition of other cell functions (Vallee \& Ulmer, 1972). Phosphatase inhibition may also account for the observed inability reported above of the lead-accumulating Citrobacter sp. to remove cadmium from solution.

The search for a relatively resistant, cadmium-accumulating organism (Macaskie \& Dean, 1982) may have resulted in the isolation of a naturally-occurring mutant resistant to $\mathrm{Cd}^{2+}$ not by exclusion of the metal from the cells, but by the production of an altered phosphatase, less susceptible to cadmium inhibition. Enzyme overproduction is not excluded as an alternative means of resistance to $\mathrm{Cd}^{2+}$, but if this were the case, then growing cells might have been expected to display a higher resistance to the metal. Studies are currently in progress to investigate this possibility. 
We are indebted to the Natural Environment Research Council (Grant no. GR3/3056) and to ERAS (International) Ltd for financial support for L.E.M.

\section{REFERENCES}

AICKIN, R. M. \& DeAN, A. C. R. (1977). Lead accumulation by microorganisms. Microbios Letters $5,129-133$

AICKIN, R. M. \& DeAN, A. C. R. (1979). Lead accumulation by Pseudomonas fluorescens and by a Citrobacter sp. Microbios Letters 9, 55-66.

Aickin, R. M., Dean, A. C. R., Cheetham, A. K. \& SKarnUlis, A. J. (1979). Electron microscope studies on the uptake of lead by a Citrobacter species. Microbios Letters 9, 7-15.

Applebury, M. L., Johnson, B. P. \& Coleman, J. E. (1970). Phosphate binding to alkaline phosphatase. Metal ion dependence. Journal of Biological Chemistry 245, 4968-4976.

BABICH, H. \& StotzKY, G. (1977). Sensitivity of various bacteria, including actinomycetes and fungi to cadmium and the influence of $\mathrm{pH}$ on sensitivity. Applied and Environmental Microbiology 33, 681695.

BABICH, H. \& StotzKY, G. (1980). Environmental factors that influence the toxicity of heavy metal and gaseous pollutants to microorganisms. CRC Critical Reviews in Microbiology 8, 99-145.

BaldRy, M. G. C. \& DEAN, A. C. R. (1980a). Copper accumulation by Escherichia coli strain FE12/5. 1. Uptake during batch culture. Microbios Letters 15, 83-87.

BaLdRY, M. G. C. \& DEAN, A. C. R. (1980 b). Copper accumulation by Escherichia coli strain FE12/5. 2. Uptake by resting organisms. Microbios Letters 15 , $105-111$.

Bolton, P. G. \& Dean, A. C. R. (1972). Phosphatase synthesis in Klebsiella (Aerobacter) aerogenes growing in continuous culture. Biochemical Journal 127, $87-96$.

BrignaC, P. J. \& Mo, C. (1975). Formation constants and metal-to-ligand ratios for tris (hydroxymethyl) amino methane-metal complexes. Analytical Chemistry 47, 1465-1466.

Chang, L. W., Reuhl, K. R. \& Wade, P. R. (1981). Pathological effects of cadmium poisoning. In Cadmium in the Environment Part II: Health Effects, pp. 783-839. Edited by J. O. Nriagu. New York: John Wiley.

CHOpRa, I. (1971). Decreased uptake of cadmium by a resistant strain of Staphylococcus aureus. Journal of General Microbiology 63, 265-267.

Doyle, J. J., Marshall, R. T. \& Pfander, W. H. (1975). Effects of cadmium on the growth and uptake of cadmium by microorganisms. Applied Microbiology 29, 562-564.

FOSTER, P. L. (1977). Copper exclusion as a mechanism of heavy metal tolerance in a green alga. Nature, London 269, 322-323.

Gноsн, A. \& Gноsн, B. К. (1972). Alkaline phosphatase derepression in vegetative cells of Bacillus subtilis by glucose, and its reversal by lactate. Biochemical and Biophysical Research Communications 46, 296-304.

Good, N. E., Winget, G. D., Winter, W., Connolly, T. N., IZAWA, S. \& SiNGH, R. M. M. (1966).
Hydrogen ion buffers for biological research. Biochemistry 5, 467-477.

HAHNE, H. C. H. \& KROONTJE, W. (1973). Significance of $\mathrm{pH}$ and chloride concentration on the behaviour of heavy metal pollutants: mercury (II), cadmium (II) and lead (II). Journal of Environmental Quality 2, $444-450$

Hassett, J. M., JenNet, J. C. \& SMith, J. E. (1980). Heavy metal accumulation by algae. In Contaminants and Sediments, vol. 2, pp. 409-424. Edited by R. A. Baker. Michigan, USA : Ann Arbor Science (Butterworth).

HUang, C. P. \& KaO, J. F. (1981). The fate, effect and control of Cd (II) in activated sludge. In Proceedings of the Third International Conference on Heavy Metals in the Environment, pp. 118-121. Edinburgh: CEP Consultants.

KOBAYASHI, J. (1970). Relation between the "itai itai" disease and the pollution of river water by cadmium from a mine. In Advances in Water Pollution Research, pp. 1-25/1-I-25/8. Edited by S. H. Jenkins. Oxford: Perganion.

Kondo, I., Ishikawa, T. \& NakahaRa, H. (1974). Mercury and cadmium resistances mediated by the penicillinase plasmid in Staphylococcus aureus. Journal of Bacteriology 117, 1-7.

Korkeala, H. \& Pekkanen, T. J. (1978). The effect of $\mathrm{pH}$ and potassium phosphate buffer on the toxicity of cadmium for bacteria. Acta veterinaria scandinavica 19, 93-101.

Lazdunski, C., Petitclerc, C. \& Lazdunski, M. (1969). Structure-function relationships for some metalloalkaline phosphatases of E. coli. European Journal of Biochemistry 8, 510-517.

MaCaskie, L. E. \& Dean, A. C. R. (1982). Cadmium accumulation by microorganisms. Encironmental Technology Letters 3, 49-56.

MClean, F. I., Lucis, O. J., Shakh, Z. A. \& Zansz, E. R. (1972). The uptake and subcellular distribution of cadmium and zinc in microorganisms. Federation Proceedings 31, 699.

NORRIS, P. R. \& Kelly, D. P. (1977). Accumulation of cadmium and cobalt by Saccharomyces cerevisiae. Journal of General Microbiology 99, 317-324.

Pickett, A. W., Carter, I. S. \& Dean, A. C. R. (1976). Enzymic activities of cadmium- and zinc-tolerant strains of Klebsiella (Aerobacter) aerogenes growing in glucose-limited chemostats. Microbios 15, 105111.

Pickett, A. W. \& Dean, A. C. R. (1976). Cadmium and zinc sensitivity and tolerance in Klebsiella (Aerobacter) aerogenes. Microbios 15, 79-91.

Pickett, A. W. \& Dean, A. C. R. (1979). Cadmium and zinc sensitivity and tolerance in Bacillus subtilis subsp. niger and in a Pseudomonas sp. Microbios 24, 51- 64.

PISCATOR, M. (1981). Current problems in research on health effects of cadmium. In Proceedings of the Third International Conference on Heary Metals in the Entironment, pp. 513-517. Edinburgh: CEP Consultants. 
Ramamoorthy, S. \& Kushner, D. J. (1975). Binding of mercuric and other heavy metal ions by microbial growth media. Microbial Ecology 2, 162-176.

STERRITT, R. M. \& LESTER, J. N. (1980a). Influence of bacterial growth on the forms of cadmium in defined culture media. Bulletin of Environmental Contamination and Toxicology 24, 196-203.

STERRITT, R. M. \& LeSTER, J. N. (1980 b). Interactions of heavy metals with bacteria. Science of the Total Environment 14, 5-17.

Strehlow, C. D. \& Barltrop, D. (1981). Indices of cadmium exposure from contaminated soils in exposed and control populations. In Proceedings of the Third International Conference on Heavy Metals in the Environment, pp. 534-537. Edinburgh: CEP Consultants.
STumm, W. L. \& BILINSKI, H. (1972). Trace metals in natural waters: difficulties of interpretation arising from our ignorance of their speciation. Advances in Water Pollution Research, pp. 39-52. Edited by S. H. Jenkins. Oxford: Pergamon.

Tynecka, Z., Zakac, J. \& Gos, Z. (1975). Plasmid dependent impermeability barrier to cadmium ion in Staphylococcus aureus. Acta microbiologica polonica, series $A$ 7, 11-20.

Vallee, B. L. \& Ulmer, D. D. (1972). Biochemical effects of mercury, cadmium and lead. Annual Review of Biochemistry 41, 91-128.

Wong, K. H., Chan, K. Y. \& NG, S. L. (1979). Cadmium uptake by the unicellular green alga Chlorella salina $\mathrm{CU}-1$ from culture media with high salinity. Chemosphere 8, 887-891. 